\title{
Sickle Cell Disease and COVID-19: Susceptibility and Severity
}

\author{
Zohreh Rahimi $^{1}$ and Babak Sayad ${ }^{1}$ \\ ${ }^{1}$ Kermanshah University of Medical Sciences
}

November 27, 2020

\begin{abstract}
Sickle cell disease (SCD) patients are immunocompromised with multiple comorbidities and a hypercoagulation state. On the other hand COVID-19 is associated with cytokine storm and hypercoagulability. To find the susceptibility and the clinical course of COVID-19 in SCD patients we surveyed related published papers from USA, Europe, Middle East, few African patients and international SCD registry. The COVID-19 presentation was mild in children and moderate in many SCD adults. To explain these findings, possible benefits of high $\mathrm{HbF}$ level, and hydroxyurea therapy could be considered. The obtained results should be interpreted considering low cases from sub-Saharan people, younger age of SCD patients compared to general population, a bias toward registry of more severe form of the disease, the influence of preexisting comorbidities with multisystem organ damage in exacerbation of the COVID-19 and the fatality rate in SCD patients and the role of health socio-economic determinants.
\end{abstract}

\section{Hosted file}

Main Sickle Cell Disease and COVID-19 and NOV. 20, 2020.pdf available at https://authorea. com/users/379250/articles/495512-sickle-cell-disease-and-covid-19-susceptibility-andseverity

\section{Hosted file}

Tables 1 and 2 and Nov.20.pdf available at https://authorea.com/users/379250/articles/495512sickle-cell-disease-and-covid-19-susceptibility-and-severity 